\title{
Beyond the emergency problematique: how do security IOs respond to crises - a case study of NATO response to COVID-19
}

\section{Cornelia Baciu ${ }^{1}$}

Accepted: 25 May 2021 / Published online: 28 June 2021

(c) The Editor of the Journal 2021

\begin{abstract}
This article explores the discourses and strategies of security international organisations (IOs) during the COVID-19 pandemic, applying NATO as a case study. To build the argument, the article analyses speeches and public interventions by the SG and DSG coded in NVivo. First, the results of the empirical analysis suggest that during the crisis NATO discourse focussed on its ability to perform core functions, on constructing identity, generating "positive" legitimacy, or on increasing the relevance of military capital. Second, the findings show that the main elements of the organisation's COVID-19 crisis management strategy were: proactiveness, continuous review and planning ahead, stepping-up activities and efficiency, lessons learned, adaptability, solidarity and civil-military cooperation. Third, a logic of IO exceptionalism and 'emergency problematique', underpinned by mission creep, could not be conclusively confirmed based on the analysed sample. The article adds a theoretical distinction to the literature on global governance in times of emergency. It demonstrates that security IOs might not always seek explicit authority leaps through lowering checks and balances (horizonal) or reducing the legal protection of subjects (vertical), due to risks of sanctioning.
\end{abstract}

Keywords Crisis management · International Organisations · Legitimacy · COVID-19 $\cdot \mathrm{NATO} \cdot$ Emergency problematique

\section{Introduction}

"Can we talk about the Coronavirus?" a journalist asked NATO Secretary General (SG), Jens Stoltenberg, during the doorstep statement a day before the Munich Security Conference 2020. The question was lost in the multitude of queries and remained

Cornelia Baciu

Cornelia.Baciu@jhu.edu

1 Institute for Peace Research and Security Policy at the University of Hamburg, Beim Schlump 83, 20144 Hamburg, Germany 
unanswered. While NATO began implementing preventive measures in January $2020,{ }^{1}$ it was not until 6 March 2020 that NATO took an official position towards COVID-19. To find out what NATO has been doing during the pandemic, why it has been doing so, and how it has fared in so doing, I examined all public interventions by the NATO SG and Deputy Secretary General (DSG), in the period between 06 March and 06 May 2020, ${ }^{2}$ capturing the immediate NATO response to the COVID19 crisis. The statements and public intervention data are complemented by press releases and other relevant strategic documents, announcements and reports. I coded the transcripts of statements or talks in NVivo, applying an inductive methodological approach and emerging coding. ${ }^{3}$ This involved a two-step analysis. First, paragraphs or sentences (units) were coded, one by one, to themes, i.e. meaningful categories that emerged during the coding process. Throughout the analysis, coding units were assigned to those emerging themes, and new categories were established as needed. In a second step, after having coded the entire material, the categories that emerged were classified into meta-themes reflected in the next two sections.

The next two sections present the major thematic clusters as they emerged from the data. The fourth section discusses the results from the perspective of the emergency problematique theory and international organisations' (IOs) exceptionalism ${ }^{4}$ in times of crises, and compares the findings to NATO responses to previous crises such as in Ukraine or Kosovo. The fifth section concludes this article by gauging the implications for the academic and policy communities and by suggesting avenues for future research.

\section{NATO as crisis manager: ensuring continuity of operative core responsibilities and performing emergency-specific tasks}

One main meta-theme to emerge from the analysis of speeches and transcripts is the dimension of NATO as a crisis manager, while simultaneously continuing the implementation of core tasks, such as deterrence and collective defence and existing missions. During public interventions and statements, both the SG Jens Stoltenberg and DSG Mircea Geoana emphasised crisis management as the ontological purpose of NATO. They also underscored the Alliance's track record-in terms of institutional shared command, control structure and operational capacity-for supporting, coordinating and mobilising civilian efforts. "NATO was created to deal with crises", it was said at a press conference, ${ }^{5}$ a statement reiterated on many subsequent occasions. NATO as crisis manager was central in the analysed discourse. The IO's crisis management mandate thus deserves a closer look.

\footnotetext{
1 As mentioned by the SG during the launch of the Annual Report 2019.

2 The approx. size of the analysed sample was over 25,000 words.

3 Michael Laver, Kenneth Benoit and John Garry, 'Extracting Policy Positions from Political Texts Using Words as Data,' Am. Pol. Sci. Rev. (American Political Science Review) 97, no. 2 (2003): 311-331.

${ }^{4}$ Christian Kreuder-Sonnen, 'International authority and the emergency problematique: IO empowerment through crises,' International Theory 11, no. 2 (2019): 182-210.

5 See: https://www.nato.int/cps/en/natohq/opinions_174772.htm?selectedLocale=en.
}

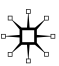


Crisis management is not mentioned per se in the Washington Treaty of 04 April 1949. However, Article 3 of the Treaty stipulates that member states shall "separately and jointly, by means of continuous and effective self-help and mutual aid, ... maintain and develop their individual and collective capacity". ${ }^{6}$ Crisis management is a core task of NATO, along with collective defence (Article 5) and cooperative security, as defined in the 2010 Strategic Concept. The question is whether the pandemic response fits within that framework and, if so, to what extent a logic of exceptionalism was embraced. Article 5 was not invoked during the pandemic. Public mentions of the scenario of invoking Article 5 to "combat the pandemic" were rather isolated. ${ }^{7}$ In the press conference following the virtual meeting of the NATO Ministers of Foreign Affairs on 03 April and the North Atlantic Council in Defence Ministers' session on 15 April 2020, Secretary General Stoltenberg provided a summary of the content discussed during those meetings. Article 5 was not mentioned in his remarks delivered to the press. Neither was Article 4 invoked as a direct response to the pandemic. When Article 4 (the consultation procedure)—which makes it possible for member states to table issues for debate at the North Atlantic Council-was invoked during the pandemic, it was by Turkey on 28 February 2020 with regard to developments in Syria not causally linked to COVID-19. Thus, as the analysed transcripts demonstrated, during the period under consideration it was Article 3 that emerged to be central to NATO's COVID-19 narrative. Article 3 was repeatedly cited in the context of NATO's mandate to ensure resilience and civil preparedness in times of crises. ${ }^{8}$

During the COVID-19 pandemic, the NATO SG and DSG highlighted the security IO's ability to perform "core" missions and activities to ensure the continuity of ongoing operations and its capacity to take on new, crisis-related, emergent tasks, such as the rapid transport and coordination of medical equipment, as one of their chief messages. Nearly every public statement provides re-assurance of NATO's operational readiness and capacity to defend and perform its core responsibilities. "[O]ur operational readiness remains undiminished. And our forces remain ready, vigilant and prepared to respond to any threat... we can deploy troops, forces if needed", declared the SG. ${ }^{9}$ Delivery of operative core responsibilities was perceived as a basic premise to maintain NATO posture and as a precondition for assuming additional tasks (emergency-specific) in a credible manner. The delivery of operative core tasks was usually operationalized "to make sure that we deliver credible

\footnotetext{
6 See Washington Treaty 1949.

7 See: https://www.atlanticcouncil.org/content-series/inflection-points/why-trump-should-trigger-natosarticle-5-vs-covid-19/.

8 See, for example, the remarks by NATO Secretary General Jens Stoltenberg following the meeting of NATO Ministers of Foreign Affairs on 02 April 2020: https://www.nato.int/cps/en/natohq/opinions_ 174772.htm?selectedLocale=en.

9 See: https://www.nato.int/cps/en/natohq/opinions_175087.htm?selectedLocale=en.
} 
deterrence and defence every day and that our forces stay ready and that we are able to act if needed". ${ }^{10}$ Other recurrent expressions attributed to NATO core responsibilities were "to make sure that this health crisis does not become a security crisis"11 and to protect and preserve security for "almost one billion people" 12 (mentioned by both SG and DSG).

During speeches, public interventions and Q\&A sessions in the studied period, eight tasks were highlighted as referring to core NATO responsibilities ongoing at the time of the COVID-19 crisis outbreak: (1) providing re-assurance in relation to the Resolute Support Mission in Afghanistan; (2) continuing NATO counterterrorism training operations in Iraq; (3) providing re-assurance, support and commitment to Turkey in response to the consultation procedure (Art. 4) that Turkey activated in the aftermath of the Idlib escalation; (4) remaining committed to the partnership with Georgia and Ukraine, both beneficiaries of international assistance under the Euro-Atlantic Disaster Response Coordination Centre (EADRCC); (5) upholding operational readiness and vigilance through air policing, patrolling, maritime operations or an increased "presence in the Black Sea Region on land with the Tailored Presence in Romania""13; (6) maintaining the four multinational battlegroups on the Eastern flank in Estonia, Latvia, Lithuania and Poland; (7) countering hybrid warfare that has intensified with the exponential surge in disinformation and cyberattacks in Europe and the USA since the pandemic began ${ }^{14}$; and, (8) continuing the NATO mission in Kosovo. The SG and DSG explained that all operative core tasks continued and were successfully fulfilled during the crisis, albeit with some limitations or at lower intensities. Arguably, a position of non-fulfilment of the mandate could have had dramatic effects for NATO's future existence. Maintaining all elements of the mandate was perceived as a precondition for the IO's resilience and for projecting effectiveness. As the DSG stated, it was "proof of the capability of NATO to withstand any pressure, any stress, even in such a complicated moment like this". 15

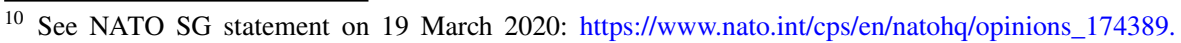
$\mathrm{htm}$ ? selectedLocale $=$ en.

11 This was also reiterated more recently, see for example, the speech of the NATO SG at the Riga Conference on 13 November 2020: https://www.nato.int/cps/en/natohq/opinions_179489.htm.

${ }^{12}$ Both expressions were mentioned numerous times during the pandemic, see for example: https:// www.nato.int/cps/en/natohq/opinions_175085.htm?selectedLocale=en.

13 This included a training exercise with the five Standing NATO Maritime Group Two ships on 30 March. See: https://mc.nato.int/media-centre/news/2020/standing-nato-maritime-group-2-exercise-withromania-in-the-black-sea-

${ }^{14}$ According to the INTERPOL Cybercrime Analysis Report of August 2020, the number of cyber phishing, scam or fraud increased by 59\%. The Report found that there was a "shift from individuals to governments and critical infrastructure", see: https://www.interpol.int/en/News-and-Events/News/2020/ INTERPOL-report-shows-alarming-rate-of-cyberattacks-during-COVID-19.

${ }^{15}$ Mircea Geoana, 'NATO Deputy Secretary General to speak on Allied response to COVID-19,' Atlantic Council, April 16, 2020, https://atlanticcouncil.org/event/allied-response-to-covid-19-a-conversationwith-mircea-geoana/.
} 


\section{Emergency-specific tasks: strategic airlift, crisis preparedness and countering disinformation}

In addition to the eight operative core tasks ongoing at the beginning of the COVID19 crisis, NATO's pandemic discourse was also related to its performance of two other major emergency-specific tasks within its mandate of maintaining readiness to respond to crises: strategic airlift and transport of essential medical equipment or patients, and assistance to member states to enhance preparedness at whole-governmental level. Resilience was perceived to be essential for the continuity of government and essential works, especially in the context of an unfolding geostrategic environment. Article 3 of the 1949 Washington Treaty was invoked as pertaining to NATO's responsibility to maintain national resilience of members. When NATO was established, in the context of the World War II, the major threat was that of an armed attack by the USSR. As NATO continues to function on the legal foundation of the 1949 Treaty, Article 3 does not mention the word "national resilience" per se, but refers to the "continuous and effective self-help and mutual aid" and maintenance and development of the collective capacity of members. ${ }^{16}$ In concrete terms, as it was explained during the statements, this meant providing member states with baseline requirements guidelines ${ }^{17}$ that NATO "developed over decades" 18 related to infrastructure, health, mass casualties, the ability to move, communication, decision-making and other critical areas. Crisis response constitutes an area in which NATO has many years of demonstrable experience and training. As it was specified by the SG in relation to the newest NATO member, North Macedonia: "over the last few years, NATO has trained more than 500 first responders in North Macedonia to improve their ability to respond to major incidents such as this". ${ }^{19}$ In the past, NATO has conducted major multinational medical exercises, for instance, Vigorous Warrior organised by the NATO Military Medicine Centre of Excellence in 2019. In the context of large-scale shocks and a rapidly evolving geostrategic environment, resilience needs to be permanently evaluated and updated. One dimension often mentioned in relation to ensuring Allies' resilience was the necessity for permanent review, as well as for updating and incorporating new dimensions linked to anticipated and evolving risks like the need to protect and assure critical infrastructure and supply chains. Thus, resilience also pertained to the collective capacity to prevent cyber-attacks and disinformation campaigns carried out by actors aiming to destabilise the society or the government apparatus to enhance their competitive advantage.

\footnotetext{
${ }^{16}$ See the North Atlantic Treaty, Washington D.C., 4 April 1949.

17 As part of its civil preparedness portfolio, NATO members agreed on seven baseline requirements. See Wolf-Diether Roepke and Hasit Thankey, 'Resilience: the first line of defence,' NATO Review, February, 2019, https://www.nato.int/docu/review/articles/2019/02/27/resilience-the-first-line-of-defence/ index.html.

18 Mircea Geoana, 'Strategic conversation with Dan Mircea Geoana, Deputy Secretary-General of the North Atlantic Treaty Organisation (NATO), Friends of Europe, April 27, 2020, https://www.friendsofe urope.org/events/strategic-conversation-with-dan-mircea-geoana-deputy-secretary-general-of-the-northatlantic-treaty-organisation-nato/

19 See: https://www.nato.int/cps/en/natohq/opinions_174616.htm.
} 
A second crisis-specific dimension to emerge from the data is related to strategic airlift of essential medical equipment such as masks, protective equipment and other medical supplies. More than 100 missions of strategic airlift and transport of patients and essential medical equipment, for example, from Italy to Germany, were conducted based on requests by NATO member states or partner countries in the period March-June 2020. This demonstrates the members and partners' readiness to participate in this solidarity and mutual help mechanism. As of 02 July 2020, seven NATO members (Spain, Bulgaria, Montenegro, Italy, Albania, the Republic of North Macedonia and Slovenia) and nine partner countries (Ukraine, Republic of Moldova, Bosnia and Herzegovina, Georgia, Colombia, Tunisia, Afghanistan, Mongolia and Iraq) had requested international assistance via NATO EADRCC. ${ }^{20}$ In addition to strategic airlift, NATO also helped build more than 25 field hospitals, and 4,000 military medical personnel joined the efforts of civilian medical staff. Public communication and speeches emphasised that the COVID-19 pandemic was at the top of the NATO agenda and that its focus was "to help the civilian authorities, the healthcare systems to combat the virus, to deal with the consequences of the COVID-19 crisis". ${ }^{21}$ In their public speeches, the SG and DSG frequently spoke of "saving lives", an overarching goal also referred to in the NATO Foreign Ministers Declaration of 2 April 2020. Strategic airlift, coordinated in conjunction with the NATO Strategic Airlift Capability (SAC), was identified and highly prioritised as a concrete solution to address specific needs on the ground. The NATO SAC was established in 2008 to fill a defence capability gap. It comprises an operational unit, the Heavy Airlift Wing (which is outside of the NATO Force Structure as operations are coordinated via NSPA, the NATO Support and Procurement Agency), and the NATO Airlift Management Programme based in Hungary. Operationally, NATO SAC relies on three Boeing C-17 Globemaster III (under the Hungarian flag) and 150 military, 60 civilian and 60 Boeing maintenance contractors. ${ }^{22}$ One drawback of the SAC is that it relies on commercial suppliers, which raises the questions of dependence and whether NATO states should acquire more C-17 aircrafts of their own. SAC has already completed over 2,500 missions, for example, providing strategic airlift to Haiti after the 2010 earthquake and to Pakistan during the 2010 flooding, and logistical support in the search for Malaysia Airlines flight MH370. ${ }^{23}$

To sum up, in its public COVID-19 discourse NATO highlighted as most important the endurance of core tasks that were ongoing at the time of the pandemic outbreak, and the fulfilment of two additional emergency-specific tasks: strategic airlift, and assisting states to maintain resilience by providing crisis preparedness guidelines and by countering disinformation in conjunction with the EU. NATO proved its utility during the crisis by providing strategic assets that were urgently needed by

\footnotetext{
${ }^{20}$ See: https://www.nato.int/nato_static_fl2014/assets/pdf/2020/7/pdf/200702-EADRCC-0107_sitrep19. pdf.

21 See, for example, the mentions by NATO SG Jens Stoltenberg at the pre-ministerial press conference on 02 April 2020: https://www.nato.int/cps/en/natohq/opinions_174770.htm?selectedLocale=ru.

${ }^{22}$ See: https://www.nspa.nato.int/news/2019/celebrating-10-years-of-the-strategic-airlift-capability.

23 Ibid.
} 
member states and partners, thus filling a vacuum that other actors or IOs would not have had sufficient capabilities to fill to the same extent. NATO's past experience in crises and crisis-specific tasks, such as strategic airlift, proved beneficial. The following section discusses the main elements of NATO's approach to the pandemic, as they emerged from the data.

\section{The main elements of NATO's discourse on crisis management strategy}

The analysis of the NATO discourse unveiled seven major elements in the organisation's COVID-19 pandemic strategy: proactiveness, continuous review and planning ahead, stepping-up activities and efficiency, lessons learned, adaptability, solidarity and civil-military cooperation.

\section{Being proactive}

As the public statements revealed, to enhance its effectiveness during the crisis, NATO embraced a proactive approach. It was explained in numerous interventions that the IO facilitated the identification of states that had a surplus of medical equipment or capacity and matched the surplus stocks with existing requests by members or partners via EADRCC. To better mobilise and coordinate this demand and supply framework, the Supreme Allied Commander Europe (SACEUR), General Tod Wolters, was tasked with coordinating the resources and, as the SG explained, "to step up and speed up the way NATO Allies are supporting each other: mobilise more resources, utilise NATO structures, mechanisms, even more, to continue to provide critical support". ${ }^{24}$ For this purpose, states were asked to notify the SACEUR of any available resources. The transfer of resources based on a supply-demand logic worked well also due to the variation in the degree to which European states and the USA were impacted by the pandemic. The NATO capacity in place, through the SAC and the NSPA, trained for this purpose, facilitated a speedy response to requests by allies and partners. NATO has also been proactive in boosting innovation. This was demonstrated by how it activated mechanisms involving private actors or experts associated with the NATO Industry Forum (comprising 3,000 companies), the NATO Innovation Board or the NATO Science and Technology Organisation, all of which were mentioned in the public communication. In this framework, start-ups, established companies, academia and think tanks in the NATO databases were proactively asked for comments, contributions or criticism "in order to do things even better in the future". ${ }^{25}$ Other concrete examples of NATO boosting innovation during the crisis included the cooperation between the NSPA and ISINNOVA, a start-up firm from Italy, to produce 3D-printed connectors able

\footnotetext{
${ }^{24}$ See: https://www.nato.int/cps/en/natohq/opinions_174925.htm?selectedLocale=en.

25 Geoana, 'Allied response to COVID-19.'.
} 
to convert snorkelling masks into emergency ventilators masks, which were donated to the Italian Civil Protection Department for distribution and use in hospitals, ${ }^{26}$ and the scientific project in the framework of NATO Science for Peace and Security Programme "to develop new tools for a rapid and accurate diagnosis of SARS-CoV-2 infection". 27

\section{Continuous review and planning ahead}

Continuous review of the NATO response to the COVID-19 crisis and the actions taken, as well as planning ahead, were identified as further important components of the crisis approach as revealed by the data. The transatlantic organisation started to look into middle- and long-term consequences of the COVID-19 pandemic and set up a mechanism of constant review of its actions, lessons learned and planning ahead. It was highlighted that the COVID-19 crisis "will have far-reaching consequences for how we think about security, and about national resilience". ${ }^{28}$ Moreover, it was stressed that the pandemic will deliver "severe shocks to the global world order" with "geopolitical and geo-economic consequences". ${ }^{29}$ The quicker the implications can be identified, the better it is from an anticipatory governance perspective. Planning how to deal with the shocks and ensure continuity of government includes endurance of telecommunications, energy supplies and other essential infrastructure as well as insurance that "civilian and military cooperation is in place". ${ }^{30}$ Getting ready for a second wave of the pandemic and starting to plan a longer-term Pandemic Response Contingency Plan were examples of thinking and planning ahead. An important implication identified by NATO in relation to the pandemic concerned the allies' capability to maintain possession of critical infrastructure in conditions of anticipated (post-pandemic) economic downturn, with repercussions on long-term security and the Alliance's ability to manage crises. "Some", the SG said, "may seek to use the economic downturn as an opening to invest in our critical industries and infrastructure". 31 As the SG and DSG both mentioned in their public communications, the pandemic revealed a series of dependencies, both by European countries and the Unites States, on Chinese production that can rapidly lead to shortages, for example, in essential medical equipment. This can have far-reaching strategic consequences. In a counterfactual exercise, if China were to acquire stocks and subsequently decision-making agency in the civil and military firms that are part of the NATO strategic airlift program, it follows that China could have an influence on future NATO operations in times of crises.

\footnotetext{
26 See: https://www.nato.int/cps/en/natohq/news_174797.htm?selectedLocale=en.

27 See: https://www.nato.int/cps/en/natohq/news_175619.htm?selectedLocale=en.

28 Mentions by the NATO SG during the pre-ministerial press conference on 14 April 2020: https:// www.nato.int/cps/en/natohq/opinions_175085.htm?selectedLocale $=$ fr.

29 Geoana, 'Allied response to COVID-19.'.

30 Ibid.

31 NATO SG following the virtual meeting of the North Atlantic Council in Defence Ministers' session, 15 April 2020: https://www.nato.int/cps/en/natohq/opinions_175087.htm?selectedLocale=en.
} 


\section{Step-up activities and efficiency, and provide help "upon demand"}

The analysed statements reveal that NATO has vigorously looked into how to enhance efficiency and coordination. Stepping-up activities usually referred to increasing the quantity of the provided assistance ("do more") and efficiency ("with higher speed") by "identifying the airlift capacity", coordinating surplus capacity or stocks ("better matching requests for support with offers from Allies and partners") and implementing "simplified procedures for Rapid Air Mobility, in coordination with Eurocontrol" to speed up the provided assistance. ${ }^{32}$ Providing re-assurance to Turkey after the activation of Article 4 was also considered proactive leadership as the SG affirmed: "I'm in constant dialogue with the Allied capitals to see whether we can further step up our assurance measures for Turkey...I will continue to also work with Allies on how we can further step up our support to Turkey". ${ }^{33}$ The vision of "doing more" was also expressed in relation to NATO efforts in the wider Middle East region and North Africa as seen by discussions on how to step-up training activities in Iraq, or how to do more for partner countries such as Tunisia or Mauritania. Leadership and mission clarity were identified by the DSG as important determinants of NATO efficiency. Precision in the mission and command structure and the absence of "fuzziness" proved to be important in the transfer of tasks and implementation, ${ }^{34}$ which in substantive terms meant providing assistance at a speedy level.

While NATO leaders aimed to increase their value added and utility by doing more and increasing efficiency, they concomitantly stressed that help and assistance were premised on formal requests by member states or partners. In relation to the visions for Middle East and North Africa, it was specified that the concrete activities of possible future assistance were not yet known, and that assistance would only be provided upon request: "we only do that if we are requested, or there's a demand for NATO activities in different forms". ${ }^{35}$ Similarly, in relation to the strategic airlift and other types of assistance in the COVID-19 context, it was underscored that the NATO response is based on national requests and needs. ${ }^{36}$

\section{Lessons learned-harnessing accumulated knowledge}

Commitment to lessons learned emerged as another key element in the NATO approach during the pandemic, based on the public statements in the analysed sample. NATO maintains a database of lessons learned through the Joint Analysis \& Lessons Learned Centre, which coordinates and provides systematic assessments and trainings, and shares newly produced knowledge. The process to integrate

\footnotetext{
32 See: https://www.nato.int/cps/en/natohq/opinions_174772.htm?selectedLocale=en.

33 See: https://www.nato.int/cps/en/natohq/opinions_175085.htm.

34 Geoana, 'Allied response to COVID-19.'.

35 See: https://www.nato.int/cps/en/natohq/opinions_175085.htm?selectedLocale $=$ fr.

36 See the NATO SG statement on 01 April 2020: https://www.nato.int/cps/en/natohq/opinions_174770. htm? selectedLocale $=$ en .
} 
lessons learned in relation to the pandemic commenced on 01 April, prior to the NATO Foreign Ministers Meeting.

One lesson learned was on resilience. During the Defence Ministers Meeting on 15 April 2020, it was agreed to integrate the identified lessons learned into the baseline resilience requirements and to maintain regular updates. ${ }^{37}$ Moreover, an initiative was started to assess the medium- and long-term implications of the crisis, including on how to strengthen resilience and enhance preparedness for future crises. Other lessons learned outlined in the public interventions related to the need to re-think dependencies on essential supplies. The need to "ask questions whether we are too dependent on production coming from outside, whether we need to produce more of this equipment in our own countries" was emphasised by Jens Stoltenberg during a pre-ministerial press conference. ${ }^{38}$ Another lesson learned highlighted in the discourse was the "close link between the civilian efforts to fight a health crisis and the ability of the military to support those efforts", as the SG remarked. ${ }^{39}$

\section{A "culture of permanent adaptability"}

A fifth theme that emerged from the analysis was the focus on the continuity of government, the IO's own operations and core responsibilities, and on adaptability as a premise for the former. One way to enhance adaptability was through partnerships and "opening" 40 up to thousands of private actors, think tanks and academic experts via a series of mechanisms in place. The Supreme Allied Commander Transformation (SACT), in Norfolk, Virginia-currently French General André Lanata-was highlighted as part of this "ecosystem". Being responsible for finding innovative solutions and making recommendations for adjustments to the NATO posture, the Allied Command Transformation plays a key role in the processes of strategic adaptation. NATO has, explained General Lanata during the Defence Ministers Meeting on 15 April, "a vast network of military and civilian professionals from Centres of Excellence, nations, scientists, medical professionals and military experts" ${ }^{41}$ that allows it to keep pace with strategic evolutions. Adaptability is perceived as inherent to NATO's continuity as a security alliance able to provide working solutions to emerging threats in an evolving strategic environment amidst the hybridisation and unpredictability of threats. NATO has adapted after each critical juncture, explained SG Jens Stoltenberg: "NATO has adapted after the end of the Cold War and [...] after 2014 when Russia illegally annexed Crimea". ${ }^{42}$ Continuous adaptation is seen to be part of the NATO raison d'être. The "culture of adaptation and lessons

\footnotetext{
37 Geoana, 'Allied response to COVID-19.'.

38 See: https://www.nato.int/cps/en/natohq/opinions_175085.htm.

39 See: https://www.defense.gov/Explore/News/Article/Article/2151837/nato-defense-ministers-discussalliances-covid-19-response/.

40 Geoana, 'Allied response to COVID-19.'.

41 See: http://www.act.nato.int/articles/nato-defence-ministers-agree-next-steps-fight-against-coronavirus.

42 See: https://www.nato.int/cps/en/natohq/opinions_175087.htm?selectedLocale=en.
}

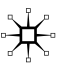


learned" constitutes a third dimension of NATO, along with its "culture of solidarity" and "culture of vigilance", as the DSG elaborated. ${ }^{43}$

The NATO Reflection Group, launched to coordinate the review process agreed to during the 2019 NATO Leaders Meeting in London, is also linked to adaptability. ${ }^{44}$ The Reflection Group was mandated to assess how to strengthen NATO's political unity, cohesiveness, solidarity and "responsiveness to new challenges". 45 The Group presented their first findings to the SG at the end of 2020. The Reflection Group was not mandated with reviewing the Strategic Concept per se, but it will nonetheless play a crucial role in NATO's future adaptability and innovation.

\section{Culture of solidarity embedded in Article 5}

The culture of solidarity, embedded in the Washington Treaty, was identified as another major element of NATO's discourse during the pandemic. The DSG stated that "Art. 5 is the ultimate expression of solidarity and also in these very difficult months and weeks of this pandemic, allies have shown solidarity". 46 The word "solidarity" was mentioned approximatively 27 times during public interactions by the SG and DSG in the studied period. Over 100 strategic airlift missions during the crisis, which required deliberate will in the capitals to share some of their medical stocks and other types of essential crisis assistance, provide evidence of the solidarity. Even in the absence of a common identity, the missions had implications at the affect level which, as will be elaborated in a subsequent section of this article, can be an important source of legitimacy. ${ }^{47}$ This was linked to previously unseen assistance dynamics. Examples include Turkey delivering medical equipment to the UK, US and Italy, and the US providing additional flying hours to Romania within the framework of the strategic airlift programme. The proactive approach together with the streamlining and acceleration of coordination and deliveries at the same time enabled and stimulated the solidarity. The value added of cooperation, mutual help and support in the context of increasing unpredictability and uncertainty, especially in times of crises, was also often highlighted in the context of NATO solidarity.

\footnotetext{
43 Geoana, 'Strategic Conversion.'.

44 For example, to adapt to a new constellation of threats, NATO declared space as one of its core domains, see: Cornelia Baciu, 'Collective Security and Art. 5 in Space: Jus Gentium, Oversight, Resilience and the Role of NATO,'Atlantic Forum, December 01, 2020, https://www.atlantic-forum.com/ content/collective-security-and-art-5-space-jus-gentium-oversight-resilience-and-role-nato.

45 Geoana, 'Allied response to COVID-19.'.

46 Geoana, 'Strategic Conversation.'.

47 Jan Aart Scholte and Jonas Tallberg, 'Theorizing the Institutional Sources of Global Governance Legitimacy,' in Legitimacy in global governance, ed. Jonas Tallberg, Karin Bäckstrand and Jan Aart Scholte. (Oxford: Oxford University Press, 2018), 56-74. See also Allen Buchanan and Robert O. Keohane, 'The Legitimacy of Global Governance Institutions,' in Legitimacy in International Law, ed. Rüdiger Wolfrum and Volker Rüben (Berlin, Heidelberg: Max-Planck-Gesellschaft zur Förderung der Wissenschaften e.V, 2008), 25-62.
} 


\section{The importance of civil-military cooperation and the role of militaries in assisting civilians}

The importance of strong civil-military partnerships and the utility of the military in the crisis was a seventh major element underscored in the NATO discourse during the COVID-19 pandemic in the studied period. For example, the SG stated that "by investing in our military, we also provide a capacity which has proven useful in supporting the civil society, dealing with crises like the corona crisis". ${ }^{48}$ The role of militaries, which ranged from dealing with military threats to assisting civilians in member countries to deal with the crisis, was often mentioned. The role of the men in uniform during the COVID-19 was perceived as a supporting one to boost civilian efforts. When asked whether global health risks should be considered when planning the defence posture, the SG emphasised that NATO should not change its core responsibilities to integrate pandemics. However, he elaborated, reviewing the possibilities of strengthening civil-military cooperation and how military capabilities could help sustain civilian efforts (in non-military operations) is worth looking into. $^{49}$

To sum up, the current and previous section presented the immediate results from the empirical analysis. I now move on to critically discuss the findings from the conceptual perspective of the emergency problematique and IO exceptionalism.

\section{Discussion of the conceptual implications: beyond the emergency problematique}

This section adds to existing literature on the emergency problematique and IO exceptionalism, by assessing the results from the perspective of legitimacy practices in IOs and global governance. Six major conceptual implications can be derived from the results.

First, as previous literature on global governance ${ }^{50}$ implied, considerable references during the COVID-19 crisis were linked to participation, fairness, expertise, effectiveness and tradition. Although broader NATO dynamics, including disputes on burden-sharing and disruptive antagonisms, were not abandoned during the pandemic, all NATO states and partners were invited to the pooling and sharing ad hoc initiative for strategic airlift of essential equipment. Participation also involved accountability and transparency, as all strategic airlift missions and crisis-related operations were documented on the NATO website. The ad hoc pooling and sharing procedure also revealed a certain degree of fairness, as all members were invited and could participate in the missions, either on the supply or the demand side, as per their needs and requests. There was no evidence of requests that could not be

\footnotetext{
48 See: https://www.nato.int/cps/en/natohq/opinions_174389.htm?selectedLocale=en.

49 See: https://www.nato.int/cps/en/natohq/opinions_175087.htm?selectedLocale=en.

${ }^{50}$ Michael Zürn, A Theory of global governance. Authority, legitimacy, and contestation (Oxford: Oxford University Press, 2018).
} 
considered. While some NATO member states are assumed to have higher agency and leverage than others despite NATO being an intergovernmental organisation requiring consensus in decision-making, no particular discrimination of states was found to be reflected in NATO statements or actions. The NATO strategic airlift operations based on a supply-demand logic and shared coordination and command, optimised under the guidance of the SACEUR and SACT, have revealed a further dimension related to fairness. This mechanism can be seen as an IO innovation, given that in the global governance system "authorities that have the capacity to significantly redistribute opportunities and wealth... hardly exist". 51 The NATO normative narrative during the COVID-19 crisis also pertained to the IO's expertise and knowledge. Crisis management was presented as NATO's raison d'être, and many references were related to its previous experience in crises, including in strategic airlift missions. NATO's previous experiences in crises, and its trainings relevant to crisis management, allowed the transatlantic organisation to quickly adapt to the situation, put mechanisms in place to coordinate tangible help and implement it rapidly in a situation in which every minute and every mask mattered. This experience proved valuable, for example, in providing states with baseline crisis pre-preparedness guidelines and in employing a lessons learned mechanism. NATO's Lessons Learned department and the systematic assessments, reviews and updates it performs demonstrate that for NATO lessons learned is already a highly institutionalised mechanism.

Second, the endogenous normative projection was less about "international responsibility" ${ }^{\prime 2}$ as it had been in previous crises ${ }^{53}$ (example, in the Ukraine ${ }^{54}$ ) and more about crisis responsibility, i.e. the obligation and authority to provide help during crises as one of NATO's core tasks, as agreed by members in the 2010 Strategic Concept. ${ }^{55}$ As the pandemic narrative demonstrated, specific attention has been dedicated to the crisis preparedness requirements, which have been made available to states and were continually reviewed and updated. In contrast to the NATO discourses during previous crises, no reference was found to be made that explicitly stated NATO as a "legitimate authority" to deal with the COVID-19 crisis. As the Alliance came under stress in recent times in relation to burden-sharing, expressed by both US President Trump and French President Macron, ${ }^{56}$ the pandemic constituted a situation for NATO to illustrate its utility and reinforce legitimacy. By proactively identifying areas in

\footnotetext{
51 Zürn, A Theory of Global Governance, 74.

52 Tal Dingott Alkopher, 'From Kosovo to Syria: the transformation of NATO Secretaries General's discourse on military humanitarian intervention,' European Security 25, no. 1 (2016): 49-71.

53 While acknowledging that crises are in principle genuinely different and can be driven by various dynamics.

54 Florian Böller, "'Guardian of the international order"? NATO's contested identity, the discourses of Secretaries General, and the Ukraine crisis,' East European Politics 34, no. 2 (2018): 217-237.

55 In addition, a recent study shows that crisis management constitutes one area of strategic overlap in the national security strategies of most NATO and EU countries, see Cornelia Baciu, 'Collaborative security regimes post-Brexit-estimating the potential for convergence based on the overlap in national strategic documents. A comparative study of EU27+1 and the US,' Comparative Strategy 39, no. 6 (2020): 549-564.

56 US President Donald Trump upended the July 2018 Brussels Summit, requesting an increase in defence budgets by European allies and threatening that contrary, he "will do its own thing". In 2019,
} 
which it can have a value added in the context of the pandemic, and by seeking to increase efficiency in providing speedy assistance in emergency-specific tasks, NATO has made use of its strategic airlift capabilities and shared command and control coordination structure, two areas in which the IO has longstanding experience and training in. The perception of a global alliance, with missions in different parts of the world, persisted only to a certain extent. Notwithstanding, the definition of a global NATO in contemporary times is quite different from early 2000s, not least because of the "dynamics in the transatlantic relationship". 57

Third, existing crisis management protocols and lessons learned database allowed the Euro-Atlantic alliance to respond in a speedy manner. The pandemic took the entire world by surprise, even its most advanced states like the USA, Germany and the UK. To cope with the pandemic, most states refocussed inwardly and declared states of emergency, which amplified the lack of leadership at both IOs and global level. This might have initially weakened supranational responses, for example, by the EU. Overall, the EU has made an enormous effort to cope with the pandemic. After lengthy negotiations, initially overshadowed by the Frugals' antagonistic position, the European Central Bank handed out 1.3 trillion EUR in a historical bondbuying package, deemed as relief for the European economy. The EU also coordinated the joint re-patriation of EU citizens abroad and, under the EU Civil Protection Mechanism and other relevant institutional structures, the IO has coordinated and financed the delivery of medical equipment within Europe and internationally. ${ }^{58}$ While the question may not be about who helped who first, the speed of the first response can play a significant role in an emergency. Lack of proper crisis management capacity, for example, meant that initial help requests from Italy did not receive an appropriate response. The President of the EU Commission Ursula von der Leyen publicly apologised to Italy, admitting it had "not been by its side since the beginning of the crisis". ${ }^{9}$ The World Health Organization (WHO) has also performed a substantial role in managing the pandemic although its actions were overshadowed by massive contestation and the US notification of withdrawal. A comprehensive comparison of the responses of the three IOs (NATO, EU, WHO), while beyond the scope of this study, can make an interesting subject for a future paper. From a pragmatic perspective, a corollary of this discussion is the delicate normative puzzle pertaining to the question of who has legitimacy to help, and who can help in times of a global shock. NATO's overall response was materially significantly lower than that of the EU, but it proved to have the capacity to speedily coordinate and take action and be a first responder while other intergovernmental organisations might have needed some time to organise and react. One possible explanation for the speedy NATO response might be the IO's assets in terms of crisis SOPs and protocols and a lesson learned database that enabled it to quickly respond to the crisis.

\footnotetext{
Footnote 56 (continued)

ahead of the NATO London High-Level Meeting, French President Emmanuel Macron stated twice that NATO is "brain-death", prompting the allies to become indignant.

57 Personal communication, 04 October 2020, Magdeburg.

58 For an overview on the EU response to COVID-19, see: https://ec.europa.eu/info/live-work-travel-eu/ health/coronavirus-response/crisis-management-and-solidarity_en.

59 See: https://www.euronews.com/2020/04/16/eu-commission-president-offers-heartfelt-apology-to-italy.
} 
Fourth, no strong evidence was found for a "relative gains" legitimation narrative-i.e. the attempt to legitimise (mandate-exceeding) action by building "on gains relative to others". ${ }^{60}$ Instead, references to IO-inner dynamics of cooperation and solidarity, identity, efficiency and "collective gains" 61 were found to be central in SG and DSG public statements. The evidence presented corroborated previous studies that pointed out the "discursive construction of NATO's identity" in times of crisis. ${ }^{62}$ During the pandemic, many references pertained to NATO's "culture of solidarity", embedded in Article 5 of the North Atlantic Treaty. Mentions of solidarity and of the need for cooperation both during and after the pandemic, as well as the re-assurance of allies and partner countries of NATO's ability to perform core responsibilities and take on additional (emergency-specific) tasks, can be interpreted as sources of "positive" legitimacy. ${ }^{63}$ Positive legitimacy can optimise IOs' internal structures and affect power relations. It can also energise implementation and thus institutional performance and identity. Recognition and support by allies are essential in light ${ }^{64}$ of the anticipated post-crisis economic downturn that might shrink domestic defence budgets which were already low before the crisis. The economic repercussions were acknowledged on many occasions during NATO's public interventions. Simultaneously, the COVID-19 narrative underscored the need for continuation of security as a precondition of trade, stability and peace. The crisis turned into an anchor point for the Alliance to show relevance, utility and ability to meet the presumed normative expectations that its member states, 42 partners and the larger public have of a collective defence organisation during a health crisis. The crisis management capacity, commitment and professionality demonstrated during the pandemic could boost perceptions of the IO's legitimacy, increase support and help avoid a potential legitimacy crisis. NATO's high level of commitment during a health crisis may have raised questions for some. A "shape-shifting" NATO was also seen during the Kosovo crisis, when the Alliance turned into a humanitarian agency and articulated a more value-orientated strategy, in which "military capital" was "made directly politically relevant". ${ }^{65}$ This approach can be conceptually drawn from notions of "active engagement" and "modern defence" that are addressed in the 2010 Strategic Concept. Furthermore, while the current Concept is ripe for renewal, the allies were for a long time somewhat nervous about opening up the discussion

\footnotetext{
60 Zürn, A Theory of Global Governance.

61 Scholte and Tallberg, 'Theorizing the Institutional Sources.'.

62 Böller, "'Guardian of the international order"?'.

63 Jennifer, Gronau and Henning Schmidtke, 'The quest for legitimacy in world politics-international institutions' legitimation strategies,' Review of International Studies 42, no. 3 (2016): 535-557. See also Jonas Tallberg and Michael Zürn. 'The legitimacy and legitimation of international organizations: introduction and framework,' The Review of International Organizations 14, no. 4 (2019): 581-606, and Hideaki Shinoda, 'The Politics of Legitimacy in International Relations: A Critical Examination of NATO's Intervention in Kosovo,' Alternatives: Global, Local, Political 25, no. 4 (2000): 515-36.

64 Sungjoon Cho, 'Toward an Identity Theory of International Organizations,' American Society of International Law 101, (2007): 157-160. See also Andrea Oelsner, 'The Institutional Identity of Regional Organizations, Or Mercosur's Identity Crisis,' International Studies Quarterly 57, no. 1 (2013): 115-127.

65 Jef Huysmans, 'Shape-Shifting NATO: Humanitarian Action and the Kosovo Refugee Crisis,' Review of International Studies, 28, no. 3 (2002): 599-618.
} 
for fear of what Trump might do. ${ }^{66}$ Military capital and professionalism in assisting civilians can be expected to remain central to NATO's future political identity.

Fifth, the rhetoric in the studied timeframe did not seek to justify decisions based on a "state of exception which requires quick decisions which are without alternative". ${ }^{67}$ Rather, it sought to do so on the basis of delivering support for shared goods and speedy outcomes (output legitimacy) along procedural patterns (input legitimacy) established on the foundation of accumulated experience. As the DSG stated, "[O]ur DNA is crisis management, our DNA is command and control, [it] is efficiency in logistics and putting together in critical moments the pieces that can make in this stress a nation and alliance work". ${ }^{68}$ NATO's supporting role under civilian oversight and democratic control was often underscored: under the civilian command "we are here with decades of experience". ${ }^{69}$ Health crises are not specified as being within the NATO mandate as defined in the Washington Treaty, although resilience and civil preparedness - including in a health context—was subsumed to NATO's portfolio more recently under Article 3. ${ }^{70}$ Applying the "IO exceptionalism" argument in the global governance literature, NATO practice during the pandemic would be seen as a source of "authority leap". ${ }^{71}$ However, the logic of exceptionalism could not be confirmed based on the data employed in this article: the examined IO has neither sought to lower checks and balances (horizontal dimension) nor to reduce the legal protection of the subjects (vertical dimension). To expedite delivery of medical equipment, a NATO call sign was used to simplify the standard procedure for military relief and speed up the Air Traffic Control clearances ${ }^{72}$ in conjunction with the Eurocontrol. This, however, did not endanger subjects as most passenger flights were suspended during the pandemic in the studied period. As the strategic and threat environment evolved with the end of the Cold War, NATO steadily adapted and became a multi-domain IO. Nonetheless, when asked by a reporter whether pandemics should receive more attention when "calculating defensive posture", the SG replied that NATO should not become "the first responder" or change its core responsibilities. But, he added, the role of militaries in civilian efforts during health crises could be further explored.

This appears a refutation of the "normalisation" thesis ${ }^{73}$ when applied to security IOs in times of pandemics. It might seem counter intuitive, especially in light of

\footnotetext{
66 Personal Communication, June 2020, Washington D.C.

67 Zürn, A Theory of Global Governance.

${ }^{68}$ Geoana, 'Allied response to COVID-19.'.

69 Ibid.

70 NATO leaders agreed to enhance national resilience and develop capacity to boost civil preparedness, "including in the health sector", drawing on the Commitment to enhance resilience issued by Heads of State and Government at the 2016 Summit in Warsaw: https://www.nato.int/cps/en/natohq/topics_49158. htm. See also: https://www.nato.int/cps/en/natohq/topics_132722.htm; https:/www.nato.int/cps/en/ natohq/official_texts_133180.htm?selectedLocale=en.

71 Kreuder-Sonnen, 'International authority and the emergency problematique.'.

72 See: https://shape.nato.int/news-archive/2020/nato-expedites-delivery-of-covid19-supplies-between-allies.

73 Kreuder-Sonnen, 'International authority and the emergency problematique.'.
}

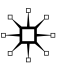


the growing securitisation literature ${ }^{74}$ and notwithstanding that crisis management is part of the core mandate of NATO. While the Alliance proactively assessed and communicated ongoing and anticipated risks, based on the analysed public interventions, there was no significant tangible evidence of "strategic reorientation". ${ }^{75}$ From a procedural perspective, the SG could not have made that determination as member states would have to agree to expand NATO's remit. Such a procedure usually takes place at the head of state level, but there have been no meetings at that level during the studied time frame. Ordinarily, such questions would be discussed during the review of the Strategic Concept which, in 2020, had been put off until after the US elections. ${ }^{76}$ The SG has nonetheless agreed upon the possibility of reviewing the role of NATO in such crises, especially from the perspective of strengthening civilmilitary cooperation.

Sixth, taken together, the empirical analysis in this article reveals interesting insights into the interplay between input and output legitimacy and how they relate to the emergency problematique. As it was pointed out numerous times in the public interventions, help and assistance to both Allies and partner countries was premised by formal demands or requests and needs on the ground. The expertise and knowledge (output legitimacy) aspect fed to a certain extent into the dimension of invoking tradition and the status quo ${ }^{77}$ as a legitimation practice. Past experience and tradition (sources of input legitimacy) in crisis management were emphasised in the statements. However, contrary to expectations derived from propositions in the specialist literature on legitimation practices in global governance, the studied narrative did not involve arguments sticking to beliefs that "something that has worked for a long time is good"-as the COVID-19 response was continually reviewed and adjusted - or that improvements can produce side-effects. ${ }^{78}$ Rather, the opposite was the case. Through the lessons learned paradigm, continuous reviewing and active monitoring of possible new intervening factors and risks, the studied IO sought to permanently update guidelines, optimise procedures and relentlessly adapt, in a rather Kuhnian dynamic of transformation and innovation. Overall, it can be said that the IO sought to transcend the emergency problematique. The evidence could not conclusively demonstrate an active counterbalancing between functional "last resort" measures and loosening constitutionalism or democratic control for the examined case. Notwithstanding this finding, the expertise that NATO demonstrated during the COVID-19 pandemic is likely to prompt future debates on NATO's role, given that, in the context of an evolving risk environment, "collective defence is

\footnotetext{
74 James Sperling and Mark Webber, 'NATO and the Ukraine crisis: Collective securitisation,' European Journal of International Security 2, no. 1 (2017): 19-46.

75 Sperling and Webber, 'NATO and the Ukraine crisis.'.

76 Personal Communication, June 2020, Washington, D.C.

77 Glen Herald Snyder and Paul Diesing, Conflict Among Nations: Bargaining, Decision Making, and System Structure in International Crises, (Princeton: Princeton University Press, 2015). See also Zürn, A Theory of Global Governance.

78 Zürn, A Theory of Global Governance, 75.
} 
being re-interpreted to mean solidarity in upholding domestic order and resilience rather than mainly protecting external borders". 79

\section{Conclusion}

This article examined NATO's discourses and strategy during the COVID-19 crisis. Drawing on all SG and DSG public interventions in the period March-May 2020 coded in NVivo, as well as on additional documentary sources, the article revealed a series of original findings that have significant implications for theory and policy. They showed that during the pandemic, NATO actions were targeted towards continuity of ongoing operative missions and taking on additional emergency-specific operations, such as strategic airlift of essential medical equipment. The IO's crisis management strategic approach during the pandemic comprised seven key elements: proactiveness; continuous review and planning ahead; stepping-up activities and efficiency and providing assistance "upon demand"; lessons learned logic; adaptability; projecting solidarity; and strengthening civil-military cooperation.

These findings make manifold contributions to the academic community. The results add a conceptual distinction to theories of global governance and IO legitimacy, specifically in relation to sources and strategies of legitimation and the exceptionalism problematique. Effectiveness as a source of IO legitimation in times of shocks can conceptually consist of elements such as proactive coordination and fair inclusion of member states, an institutional lessons learned logic, continuous review of processes and potential risks, and planning ahead. When IOs employ intensive adaptation, their ontological purpose transcends survival, and instead is concerned with developing evolutionary stable strategies, ${ }^{80}$ i.e. strategies that can remain stable over time. As rational actors, security IOs might not always seek explicit authority leaps through lowering checks and balances (horizonal) or reducing legal protection of subjects (vertical), due to risks of sanctioning-e.g. by member states principals, citizens or wider public opinion, including media and think tanks. In times of crises, IOs can transcend the emergency problematique by complying to procedural patterns and distributive justice principles (input legitimacy) and demonstrating utility and value added (output legitimacy). In order to avoid a legitimacy deficit, IOs might refrain from mission expansion beyond the scope of their mandate during a crisis. As the case under investigation demonstrated, all operations in this case were premised by formal requests and demands by receivers of assistance or hosts of operations. The concrete response, steps and actions were accurately documented on the NATO official website, which can re-enforce transparency and accountability. While deviation from procedural patterns might be possible, as the change in the flying procedure in coordination with

\footnotetext{
79 Jamie Shea, 'Never waste a good crisis: are pandemics NATO's new security challenge?' Friends of Europe, April 06, 2020, https://www.friendsofeurope.org/insights/never-waste-a-good-crisis-are-pande mics-natos-new-security-challenge/. See also Gabrielle Marceau, 'IGOs in Crisis? Or New Opportunities to Demonstrate Responsibility?' International Organizations Law Review 8, no. 1 (2011): 1-13.

${ }^{80}$ See Cornelia-Adriana Baciu and Alexandra M Friede, 'The EU's CFSP/CSDP in 2030: Towards an alternative vision of power?' New Perspectives 28, no. 3 (2020): 398-412.
} 
Eurocontrol demonstrated, these shall not be automatically equated with horizontal or vertical authority leaps. Precisely, ad hoc operational innovations might be meaningful rather than harmful to the IO's authority boundaries or subjects.

At policy level, the findings suggested both continuity and change in NATO discourse during pervasive shocks. The IO's strategy was found to be focussed on core responsibilities, NATO identity and the importance of military capital. In contrast to the narrative during previous crises, the endogenous normative themes pertained less to "international responsibility" than it did to crisis responsibility. The results showed that one lesson learned for NATO alludes to the NSPA and the Heavy Airlift Wing of the Strategic Airlift Capability. In light of the enormous costs it involves for civilian and military contractors and the risk that strategic players may aim to acquire military assets in Europe, the prospect of decreasing a possible dependency by, for example, working with national assets, ${ }^{81}$ might be due for assessment.

Little was known before about the strategy and legitimacy practices of security IOs, such as NATO, in times of large-scale health shocks. Thanks to its empirical approach, the article made a series of significant contributions in terms of theoretical innovations and additions to existing literature on global governance legitimacy in disruptive times. Future research on IOs and legitimacy in times of crises and in emerging geopolitical turbulences should take into account the importance of distinguishing between the IO's ongoing operative responsibilities and its emergency-specific operations. Strategies of legitimation in global governance in times of crises can be shaped by awareness of power relations and authority boundaries. Upcoming studies could apply a comparative design by examining further cases such as the EU or the WHO. They could also seek to unpack the conceptual implications and possible overlap between different elements of the IOs' crisis discourse and how they help to maintain a good equilibrium between mandate limitations and genuine needs on the ground. From the perspective of the emergency problematique, future research should elaborate on the trade-off between pragmatism as a source of normative legitimacy (morality) and boundaries of constitutionalism (legality) in relation to utility and societal needs on the ground.

Acknowledgements The author would like to thank to Dr. Daniel Hamilton, Austrian Marshall Plan Foundation Senior Fellow at the Henry A. Kissinger Center for Global Affairs, Johns Hopkins University and Director of the Global Europe Program at the Wilson Center, Washington, D.C., for substantive comments and ideas provided to a previous version of this article. The author would also like to extend her gratitude to the two anonymous reviewers for the provided comments, which were extremely beneficial to advance the argument made in this article. Tremendous thanks to the Editor of the Journal of Transatlantic Studies, for the kind patience throughout the review process.

Funding This article was conceived and submitted while the author was a postdoctoral researcher at the School of Advanced International Studies, Johns Hopkins University in Washington, D.C. on a fellowship sponsored by the German Academic Exchange Service (DAAD).

\section{Declarations}

Conflict of interest The author declares that she has no conflict of interest.

${ }_{81}$ See: https://www.nato.int/cps/en/natohq/opinions_175087.htm. 


\section{References}

Baciu, Cornelia. 2020a. Collaborative security regimes post-Brexit-estimating the potential for convergence based on the overlap in national strategic documents. A comparative study of EU27 +1 and the US. Comparative Strategy 39 (6): 549-564. https://doi.org/10.1080/01495933.2020.1826845.

Baciu, Cornelia-Adriana, and Alexandra M. Friede. 2020. The EU's CFSP/CSDP in 2030: Towards an alternative vision of power? New Perspectives 28 (3): 398-412. https://doi.org/10.1177/23368 25X20935245.

Baciu, Cornelia. Collective Security and Art. 5 in Space: Jus Gentium, Oversight, Resilience and the Role of NATO, Atlantic Forum, December 2020. Accessed 05 March 2021. https://www.atlantic-forum. com/content/collective-security-and-art-5-space-jus-gentium-oversight-resilience-and-role-nato.

Bäckstrand, Karin and Fredrik Söderbaum. Legitimation and delegitimation in global governance: Discursive, institutional, and behavioral practices. In Legitimacy in global governance: Sources, processes, and consequences, eds. Jonas Tallberg, Karin Bäckstrand and Jan A. Scholte, 101-18. Oxford, United Kingdom: Oxford University Press, 2018.

Böller, Florian. 2018. "Guardian of the international order"? NATO's contested identity, the discourses of Secretaries General, and the Ukraine crisis. East European Politics 34 (2): 217-237. https://doi.org/ 10.1080/21599165.2018.1458616.

Buchanan, Allen and Robert O. Keohane. The legitimacy of global governance institutions. In Legitimacy in International Law, ed. Rüdiger Wolfrum and Volker Roeben, 25-62. Berlin, Heidelberg: MaxPlanck-Gesellschaft zur Förderung der Wissenschaften e.V., 2008.

Cho, Sungjoon. 2007. Toward an Identity Theory of International Organizations. Proceedings of the Annual Meeting (American Society of International Law) 101: 157-160.

Dingott Alkopher, Tal. 2016. From Kosovo to Syria: The transformation of NATO Secretaries General's discourse on military humanitarian intervention. European Security 25 (1): 49-71. https://doi.org/ 10.1080/09662839.2015.1082128.

Marceau, Gabrielle. 2011. IGOs in crisis? Or new opportunities to demonstrate responsibility? International Organizations Law Review 8 (1): 1-13. https://doi.org/10.1163/157237411X594218.

Geoana, Mircea. NATO Deputy Secretary General to speak on Allied response to COVID-19, Atlantic Council, 16 April 2020. Accessed 07 May 2020. https://atlanticcouncil.org/event/allied-response-tocovid-19-a-conversation-with-mircea-geoana/.

Geoana, Mircea. Strategic conversation with Dan Mircea Geoana, Deputy Secretary-General of the North Atlantic Treaty Organisation (NATO), Friends of Europe, 27 April 2020. Accessed 07 May 2020. https://www.friendsofeurope.org/events/strategic-conversation-with-dan-mircea-geoana-deputysecretary-general-of-the-north-atlantic-treaty-organisation-nato/.

Gronau, Jennifer, and Henning Schmidtke. 2016. The quest for legitimacy in world politics-International institutions' legitimation strategies. Review of International Studies 42 (3): 535-557. https:// doi.org/10.1017/S0260210515000492.

Huysmans, Jef. 2002. Shape-Shifting NATO: Humanitarian action and the Kosovo refugee crisis. Review of International Studies 28 (3): 599-618.

Jonas Tallberg and Michael Zürn. 2019. The legitimacy and legitimation of international organizations: Introduction and framework. The Review of International Organizations 14 (4): 581-606. https:// doi.org/10.1007/s11558-018-9330-7.

Kreuder-Sonnen, Christian. 2019. International authority and the emergency problematique: IO empowerment through crises. International Theory 11 (2): 182-210. https://doi.org/10.1017/S175297191 9000010.

Laver, Michael, Kenneth Benoit, and John Garry. 2003. Extracting policy positions from political texts using words as data. American Political Science Review 97 (02): 311-331. https://doi.org/10.1017/ S0003055403000698.

Marceau, Gabrielle. 2011. IGOs in crisis? Or new opportunities to demonstrate responsibility? International Organizations Law Review 8 (1): 1-13. https://doi.org/10.1163/157237411X594218.

Oelsner, Andrea. 2013. The institutional identity of regional organizations, or Mercosur's identity crisis. International Studies Quarterly 57 (1): 115-127. https://doi.org/10.1111/isqu.12033.

Roepke, Wolf-Diether and Hasit Thankey, Resilience: The first line of defence, NATO Review, February 2019. Accessed 12 March 2021. https://www.nato.int/docu/review/articles/2019/02/27/resiliencethe-first-line-of-defence/index.html. 
Scholte, Jan A. and Jonas Tallberg. Theorizing the institutional sources of global governance legitimacy. In Legitimacy in global governance: Sources, processes, and consequences, eds. Jonas Tallberg, Karin Bäckstrand and Jan A. Scholte, 56-74. Oxford, United Kingdom: Oxford University Press, 2018.

Shea, Jamie. Never waste a good crisis: Are pandemics NATO's new security challenge? Friends of Europe, 6 April 2020. Accessed 05 March 2021. https://www.friendsofeurope.org/insights/neverwaste-a-good-crisis-are-pandemics-natos-new-security-challenge/.

Shinoda, Hideaki. 2000. The politics of legitimacy in international relations: A critical examination of NATO's intervention in Kosovo. Alternatives Global, Local, Political 25 (4): 515-536. https://doi. org/10.1177/030437540002500405.

Snyder, G.H., and P. Diesing. 2015. Conflict among nations: Bargaining, decision making, and system structure in international crises. Princeton: Princeton University Press.

Sperling, James, and Mark Webber. 2017. NATO and the Ukraine crisis: Collective securitisation. European Journal of International Security 2 (1): 19-46. https://doi.org/10.1017/eis.2016.17.

Tallberg, Jonas, K. Bäckstrand and J. Aart Scholte, eds. 2018. Legitimacy in global governance: Sources, processes, and consequences. Oxford: Oxford University Press.

Zürn, Michael. 2018. A theory of global governance: Authority, legitimacy, and contestation. Oxford: Oxford University Press.

Publisher's Note Springer Nature remains neutral with regard to jurisdictional claims in published maps and institutional affiliations.

Cornelia Baciu is a Postdoctoral Researcher in European Security at the Institute for Peace Research and Security Policy at the University of Hamburg, Germany, and was 2019-2020 DAAD-Postdoctoral Fellow in the programme 'United States, Europe, and World Order' at the Foreign Policy Institute and Henry A. Kissinger Center for Global Affairs, Johns Hopkins University in Washington, D.C. She researches US and EU security and foreign policy, international security organisations (UN, EU, NATO), civil-military relations, risk management, and comparative peace strategy. She has a $\mathrm{PhD}$ from the School of Law and Government, Dublin City University and was visiting researcher at the Center for War Studies, University of Southern Denmark. Dr. Baciu published two books: Peace, Security and Defence Cooperation in PostBrexit Europe. Risks and Opportunities (co-edited with John Doyle, Springer, 2019), and Civil-Military Relations and Global Security Governance. Strategy, Hybrid Orders and the Case of Pakistan (Routledge, 2021). She is Deputy Convenor of the BISA Foreign Policy Working Group and founding Director of the Research Network 'European Security and Strategy'. She was awarded with BISA, LSRS and VEUK prizes for her research and teaching. 